\title{
The Operation of Article 4 of Rome II Regulation in English and Irish Courts
}

\author{
Chukwuma Samuel Adesina Okoli* \\ Emma Roberts**
}

\begin{abstract}
This article makes a critical assessment of the operation of Article 4 of Rome II in English and Irish courts measuring the extent to which judges of England and Wales (hereafter England) and Ireland are interpreting Article 4 of Rome II in accordance with what the EU legislator intended.
\end{abstract}

Keywords: Rome II; General Rule; English and Irish case law.

\section{A. Introduction}

The law that applies to cross-border non-contractual obligations is of considerable significance. In the European Union ("EU”), cross-border non-contractual obligations are governed by Rome II Regulation. ${ }^{1}$

\footnotetext{
${ }^{*}$ Postdoctoral Researcher in Private International Law at the TMC Asser Institute, Barrister and Solicitor of the Supreme Court of Nigeria, LLM with Distinction (International Commercial Law) University of Aberdeen, Ph.D (Private International Law) University of Luxembourg. The article is another development of my LLM dissertation at the University of Aberdeen, a development of a different aspect of which was published as CSA Okoli and GO Arishe, "The Operation of the Escape Clauses in the Rome Convention, Rome I Regulation and Rome II Regulation" (2012) 8 Journal of Private International Law 513. It is also a research output of my $\mathrm{PhD}$ programme at the University of Luxembourg, funded by the Luxembourg National Research Fund - https://www.fnr.lu/projects/the-significance-of-escape-clauses-andtheir-associated-connecting-factors-in-european-union-applicable-law-rules-in-the-law-of-obligations-2/ (accessed 19 September 2019). Aspects of the draft article were presented at the IX Spanish Private International Law Conference, University of Complutense, Madrid, Spain on $22^{\text {nd }}$ of May 2015. Many thanks are due to the anonymous referees of this article for their valuable comments and criticisms. The authors also thank Dr. Eghosa Ekhator for his support on the initial draft of this article. The authors accept sole responsibility for the content of this article.
}

** LL.B. (Hons.), PGCertHE, PhD (Wales), SFHEA, Senior Lecturer in Law, University of Chester.

${ }^{1}$ Regulation (EC) No 864/2007 of the European Parliament and of the Council of 11 July 2007 on the law applicable to non-contractual obligations [2007] OJ L199/40 ("Rome II"). It takes effect in courts of Member States only for events giving rise to damage occurring after 11 January 2009, as decided by the Court of Justice of the European Union (CJEU) in Case C-412/10 Homawoo EU:C:2011:747 [37]. The English courts in Innovia Films Limited v Frito-Lay North America Inc [2012] EWHC 790 [100]; VTB Capital Plc v Nutritek International Corp [2012] EWCA Civ 808 [145]; and Alliance Bank JSC v Aquanta Corp [2012] EWCA [37]-[38] have followed the CJEU's decision in Homawoo. However, Burton J in Alliance Bank [37]-[38] queries the CJEU's decision as not clearing the doubt as to whether the date that applies is the one when the damage manifests itself or the event that gives rise to the resulting damage. He reluctantly prefers the former interpretation on the ground that Art 4(1) and Art 4(2) Rome II are concerned with the "law of the country where the damage occurs", despite the fact that the escape clause in Art 4(3) apparently does not restrict itself to the general rules in Art 4(1) and Art 4(2). See also earlier English cases on the controversy as to when Rome II comes into operation: Bonsall v Cattolica Assicurazioni [2010] ILPR 45 [8]; Bacon v Nacional Suizaciga [2010] EHWC 2017 (QB) [61]; Homawoo v GMF Assurance [2010] EHWC 1941 [43]-[52]; Lucas Film Limited v Ainsworth [2011] UKSC 39 [91]; Hillside (New Media) Limited v Biarte Baasland [2010] EHWC 1941 (QB) [23]-[25]. 
The law that applies in the absence of choice ${ }^{2}$ for non-contractual obligations is the general rule. $^{3}$ Article 4 of Rome II is the "central provision" 4 of Rome II - it applies to all cross-border noncontractual obligations that are not otherwise governed by specific rules. ${ }^{5}$ This explains why this article singles out Article 4 of Rome II for analysis. Rome II has now been in operation for over ten years and a common law jurisprudence ${ }^{6}$ on the operation of Article 4 has developed; thus, it is an area ripe for analysis.

This article focuses on all the decided cases on Article 4 of Rome II in English and Irish courts. ${ }^{7}$ It makes a key contribution in its critical assessment of the extent to which judges of England and Ireland are interpreting Article 4 of Rome II in accordance with what the EU legislator intended.

The United Kingdom's exit from the EU ("Brexit") ${ }^{8}$ and its possible effect upon the operation of Article 4 of Rome II is beyond the scope of this article. ${ }^{9}$ As Professor Dickinson rightly submits, any discussion on how private international law would be affected by Brexit is speculative. ${ }^{10}$ We decline the honour to engage in such speculation.

Part B of this article briefly outlines the framework of Article 4 of Rome II, C critically analyses the operation of Article 4(1) of Rome II, D critically analyses the operation of Article 4(2) of Rome II, E critically analyses the operation of Article 4(3) of Rome II and F gives a conclusion.

\section{B. Framework of Article 4 of Rome II Regulation}

It is important to set out the terms of Article 4 of Rome II for the sake of clarity:

\footnotetext{
${ }^{2}$ See Art 14 of Rome II on party autonomy for non-contractual obligations.

${ }^{3}$ See Folkes v Generali Assurances [2019] EWHC 801 (QB) [8] (Nicol J). Cf. Art 3 of Rome I Regulation (Regulation (EC) No 593/2008 of the European Parliament and of the Council of 17 June 2008 on the law applicable to contractual obligations [2008] OJ L177/6 ("Rome I"). Art 29 Rome I provides that it shall apply from 17 December 2009. It replaces the Rome Convention - [1980] OJ L266.) See also Recital 11 to Rome I.

${ }^{4}$ SC Symeonides, "Rome II and Tort Conflicts: A Missed Opportunity" (2008) 56 American Journal of Comparative Law $173,186$.

${ }^{5}$ See Arts $5-12$ of Rome II.

${ }^{6}$ In common law jurisprudence, L Collins (ed) Dicey, Morris \& Collins, The Conflict of Laws $\left(15^{\text {th }}\right.$ edn, Sweet and Maxwell, 2012) and A Dickinson, The Rome II Regulation: The Law Applicable to Non-Contractual Obligations (Oxford University Press, 2008) are very influential texts on the subject of Rome II. Indeed, very recently Bryan J in Angola $v$ Perfectbit Ltd [2018] EWHC 965 (Comm) [200] crowned these works as "the leading texts" on the subject of Rome II. See also J Ahern and W Binchy (eds.), The Rome II Regulation on the Law Applicable to Non-Contractual-Obligations: A New International Litigation Regime (Martinus Nijhoff, 2009).

${ }^{7}$ English and Irish courts are also referred to as "Common law courts" in this article.

${ }^{8}$ On $24^{\text {th }}$ June 2016 the majority of the United Kingdom voted in a referendum to leave the European Union triggering Art 50 of the Treaty of the European Union.

"See for example A Dickinson, "Back to the Future: the UK's EU Exit and the Conflict of Laws" (2016) 12 Journal of Private International Law 195; E Lein, "Unchartered territory? A few thoughts on Private International law Post Brexit" (2015/2016) XVII Yearbook of Private International Law 33; M Pilich, "Brexit and EU Private International Law: May the EU Stay in?" (2017) Maastricht Journal of European and Comparative Law 1-17; J Fitchen, “The Private International Law Consequences of Brexit" (2017) 35 Nederlands Internationaal Privaatrecht 411-432; G Rühl, "Judicial Cooperation In Civil And Commercial Matters After Brexit: which way forward?" (2018) 67 International and Comparative Law Quarterly 99; Z Tang, "UK-EU Civil Judicial Co-operation after Brexit: Five Models" (2018) 43 European Law Review 648.

${ }^{10}$ Dickinson (n 9).
} 
1. Unless otherwise provided for in this Regulation, the law applicable to a non-contractual obligation arising out of a tort/delict shall be the law of the country in which the damage occurs irrespective of the country in which the event giving rise to the damage occurred and irrespective of the country or countries in which the indirect consequences of that event occur.

2. However, where the person claimed to be liable and the person sustaining damage both have their habitual residence in the same country at the time when the damage occurs, the law of that country shall apply.

3. Where it is clear from all the circumstances of the case that the tort/delict is manifestly more closely connected with a country other than that indicated in paragraphs 1 or 2 , the law of that other country shall apply. A manifestly closer connection with another country might be based in particular on a preexisting relationship between the parties, such as a contract, that is closely connected with the tort/delict in question.

The common law case law applying Article 4 of Rome II tells us five things about Article 4's framework. First, it is to be applied autonomously. ${ }^{11}$ Second, it excludes judge made dépeçage. ${ }^{12}$ Third, it excludes substantive justice principles or better law approach. ${ }^{13}$ Fourth, it prevails over recitals. ${ }^{14}$ Fifth, it is affected by matters of common law procedure and evidence ${ }^{15}$ such that the applicable law is determined tentatively in interlocutory proceedings, ${ }^{16}$ and the onus is on the parties (not the judge) to prove the content of foreign law, if not the judge would assume that foreign law is the same as the law of the forum. ${ }^{17}$

\footnotetext{
${ }^{11}$ Recital 11 to Rome II. See generally Ertse Group Bank AG, London Branch v JSC 'VMZ' Red October \& Ors [2015] EWCA Civ 379 [90]-[96]; Hillside (n 1) [28]. See also Committeri v Club Mediterranee Sa Generali Assurances Iard Sa [2016] EWHC 1510 [33], [40]-[49]. For pre-Rome II law on this subject see Phillips v Eyre [1870] L.R. 6 QB 1, 28; Boys $v$ Chaplin [1971] AC 356; Red Sea Insurance Co. Ltd. Appellant v Bouygues S.A [1995] 3 WLR 926; S 11 and 12 of the Private International Law (Miscellaneous Provisions) Act 1995.

${ }^{12}$ See generally ICDL GCC Foundation FZ-LLC and others v European Computer Driving Licence Foundation Ltd [2011] IEHC 343 [9.7] (Clarke J); Alfa Laval Tumba AB \& Alfa Laval Krakow v Separator Spares International Ltd [2012] EWHC 1155 [21] - [24] (Arnold J); Case C-133/08 Intercontainer Interfrigo SC (ICF) v Balkenende Oosthuizen EU:C:2009:617 [42]-[49]; Giuliano-Lagarde Report [1980] OJ C282/1, 23. See also Jacobs v MIB [2010] EWHC 231 [46] (Owen J); Stylianou v Toyoshima [2013] EWHC 2188 (QB) (Sir Robert Nelson J); Fortress Value Fund v Blue Skye Fund [2013] EWHC (Comm) 1486; Wall v Mutuelle de Poitiers Assurances [2014] EWCA Civ 138 [16]-[20] (Longmore LJ), [34]-[36] (Jackson LJ), [47]-[53] (Christopher Clarke LJ); Winrow v Hemphill [2015] I.L.Pr. 12 [45] (Slade J); Moreno v The Motor Insurer's Bureau [2015] EWCA Civ 379 [43], [73]-[78] (Gilbart J); Erste Group (ibid) [91].

${ }^{13}$ See generally Jacobs (ibid); Winrow (ibid). See also DF Cavers, "A Critique of the Choice-of-Law Problem" (1933) 47 Harvard Law Review 173; FC Von Savigny, Private International Law - A Treatise on the Conflict of Laws (William Guthrie trans, T \& T Law Publishers, 1869) 110-11,114, 248.

${ }^{14}$ Stylianou (n 12) [33], [75]-[78]; Winrow (n 12) [58]-[59].

${ }^{15}$ Art 1(3) of Rome II. See also Art 1(3) of Rome II.

${ }^{16}$ Allied Irish Bank Plc and others v Diamond and others [2011] IEHC 505; Alfa Laval (n 12); Alliance Bank (n 1); Stylianou (n 12) [22]; Fortress Value (n 12) [56]-[59]; Erste Group (n 11) [99]. See also C\&F Green Energy Ltd \& anor v Bakker Magnetics BV [2015] IEHC 773 and Banque Cantonale de Genéve v Plolevent Ltd and others [2015] EWHC 1968 (Comm) (Teare J).

${ }^{17}$ Alliance Bank JSC v Aquanta Corporation [2011] EWHC 3281 (Comm) [41] (Burton J); Stylianou (n 12) [22]; OPO v MLA [2014] EWCA Civ 1277 [108]-[111] (Arden LJ); James Rhodes v OPO [2015] UKSC 32 [121] (Lord Neuberger); Lady Christine Brownlie v Four seasons Holdings Incorporated ("Brownlie ") [2015] EWCA Civ 665 [45], [89], [92] (Arden LJ); Fundo Soberano de Angola v Jose Filomeno dos Santos [2018] EWHC 2199 (Comm) [32] (Popplewell J); Tremendous Success Holdings Ltd v Sinosoft Technology Group Ltd [2016] HKEC 1509 (Anita Yip J) [45].
} 


\section{Article 4(1) of Rome II Regulation}

Article 4 (1) of Rome II is the principal connecting factor under Rome II. In this connection Recital 18 to Rome II provides that: "The general rule in this Regulation should be the lex loci damni provided for in Article 4(1).” Recitals 16 and 17 provide the following guidance on Article 4(1) of Rome II:

(16) Uniform rules should enhance the foreseeability of court decisions and ensure a reasonable balance between the interests of the person claimed to be liable and the person who has sustained damage. A connection with the country where the direct damage occurred (lex loci damni) strikes a fair balance between the interests of the person claimed to be liable and the person sustaining the damage, and also reflects the modern approach to civil liability and the development of systems of strict liability.

(17) The law applicable should be determined on the basis of where the damage occurs, regardless of the country or countries in which the indirect consequences could occur. Accordingly, in cases of personal injury or damage to property, the country in which the damage occurs should be the country where the injury was sustained or the property was damaged respectively.

Some other points are worth noting. First, Article 4(1) of Rome II is a fixed rule and not a presumption. ${ }^{18}$ Article 4(1) of Rome II is not in the same form or structure as Article 4(2) of the Rome Convention. Article 4(2) of the Rome Convention is a presumption of closest connection for contractual obligations, while Article 4(1) of Rome II is the general rule embodying the principal connecting factor that indicates the law, which applies for non-contractual obligations.

Second, common law judges agree that the time at which the damage is sustained, is used in applying Article 4(1) of Rome II, and not the time at which proceedings are instituted. ${ }^{19}$ For example, if $\mathrm{A}$ injures $\mathrm{B}$ in a traffic accident, the time at which damage is sustained is the moment the injury occurred during the road accident. Any other damage B suffers at the time of instituting proceedings is irrelevant under Article 4(1) of Rome II. Moreover, any other damage sustained at the time of instituting the proceedings in court would constitute the country in which the indirect consequences of that event occur, and is clearly irrelevant for the purpose of Article 4(1).

Third, common law judges agree that Article 4(1) of Rome II is applied to damage that has occurred, ${ }^{20}$ and "not likely to occur." ${ }^{21}$ For example if there is a threat that the actions of A are likely to cause financial damage to B. B cannot invoke Article 4(1) because the financial damage is yet to occur.

\footnotetext{
${ }^{18}$ Moreno (n 12) [47].

${ }^{19}$ See generally Daniela Bianco v Anthony J Bennett [2015] EWHC 626 (QB) [28]. See also Jacobs (n 12); Winrow (n 12) [46].

${ }^{20} \mathrm{Cf}$. Art 7(2) of Brussels Ia in the allocation of jurisdiction for non-contractual obligations in the EU applies the connecting factor of the place of harmful event to damage that has occurred or may occur.

${ }^{21} O P O(\mathrm{n} 17)[112]$ (Arden LJ). 
There are two controversial issues raised in respect of Article 4(1) of Rome II in common law courts. First, is Article 4 of Rome II to be given an equivalent or parallel interpretation with Article 7(2) of Brussels Ia ${ }^{22}$ and its predecessor instruments? ${ }^{23}$ Second, what solution is to be applied where the place of damage occurs in different countries simultaneously? These issues are considered separately.

\section{Coherence between Article 4(1) of Rome II Regulation and Article 7(2) of Brussels Ia.}

Article 7(2) of Brussels Ia provides that:

A person domiciled in a Member State may be sued in another Member State in matters relating to tort, delict or quasi-delict, in the courts for the place where the harmful event occurred or may occur. In effect, Article 4(1) of Rome II applies the lex loci damni to choice of law for non-contractual obligations, while Article 7(2) of Brussels Ia applies the place of harmful event to non-contractual obligations in the EU allocation of jurisdiction.

It is important to note that there is a real conceptual distinction between the lex loci damni under Article 4 of Rome II, and the place of harmful event in Article 7(2) of Brussels Ia. The lex loci damni under Article 4 of Rome II is only concerned with where the victim suffered direct damage, ${ }^{24}$ while the place of harmful event under Article 7 (2) Brussels Ia covers the place giving rise to the damage, and the place where the direct damage occurred. ${ }^{25}$ In other words, Article 4 of Rome II excludes the place giving rise to the direct damage. This distinction is key.

To make the above point concrete, reference is made to locus classicus of Bier v Mines de Potasse d'Alsace ("Bier"), ${ }^{26}$ which created the choice between the place giving rise to the damage and the place where the damage manifests itself in the EU allocation of jurisdiction rules for noncontractual obligations. The Bier case involved a claim by the claimant against the defendant for a harmful event caused by pollution into the River Rhine in France, which allegedly caused damage to the claimant's plantations in The Netherlands. The ECJ held that the claimant could either sue in

\footnotetext{
${ }^{22}$ Council Regulation (EU) No 1215/2012 of the European Parliament and of the Council of 12 December 2012 [2012] OJ L351/1 ("Brussels Ia").

${ }^{23}$ Convention on Jurisdiction and Enforcement of Judgments in Civil and Commercial Matters, as amended [1998] OJ C27/1 ("Brussels Convention"); Council Regulation (EC) 44/2001 of 22 December 2000 on Jurisdiction and the Recognition and Enforcement of Judgments in Civil and Commercial Matters [2001] OJ L12/1 ("Brussels I Regulation").

${ }^{24}$ See also ED\&F Man Capital Markets Ltd v Come Harvest Holdings Ltd [2019] EWHC 1661 (Comm) [61] (Daniel Toledano QC).

${ }^{25}$ See generally Case C-21/76 Bier, EU:C:1976:166; Case C-220/88, Dumez France, EU:C:1990:8; Case C-68/93 Shevill, EU:C:1995:6; Case C-364/93, Marinari EU:C:1995:289; Case C-167/00, Verein für Konsumenteninformation EU:C:2002:555; Case C-18/02, Danmarks EU:C:2004:74; Case C-189/08, Zuid-Chemie EU:C:2009:475 [24]; Case C133/11, Folien Fischer EU:C:2012:664; Case C-228/11, Melzer EU:C:2013:305; Case C-147/12, Öfab EU:C:2013:490; Case C-45/13, Kainz EU:C:2014:7 [27]; Case C-572/14, Austro-Mechana EU:C:2013:515; Case C-352/13, Hydrogen Peroxide EU:C:2015:335 [40]; Case C-47/14, Holterman EU:C:2015:574; C-12/15, Universal Music International EU:C:2016:449.

${ }^{26}$ Ibid. 
France (place giving rise to the damage) or The Netherlands (place where the direct damage manifests itself). If the Bier case were to be considered in the context of Article 4(1) of Rome II, only Dutch law would be applicable since it is the place of direct damage and not the place giving rise to the damage (France).

What remains open to question is whether a parallel or equivalent interpretation of the concept of direct damage under Article 7(2) of Brussels Ia should mirror Article 4(1) of Rome II, given that they both exclude indirect consequences of the non-contractual obligation. ${ }^{27}$ Recital 7 to Rome II shows that this question is resolved in the positive:

The substantive scope and the provisions of this Regulation should be consistent with Council

Regulation (EC) No 44/2001 of 22 December 2000 on jurisdiction and the recognition and enforcement of judgments in civil and commercial matters (Brussels I) and the instruments dealing with the law applicable to contractual obligations. ${ }^{28}$

Indeed, common law judges have adopted this approach of coherence of interpretation between Article 7(2) of Brussels Ia and Article 4(1) of Rome II. ${ }^{29}$ This approach is legitimate and correct.

However, the CJEU has explicitly expressed reservations about the coherence of interpretation. In Kainz v. Pantherwerke AG, (“Kainz") ${ }^{30}$ it held that:

It must be stated next that, although it is apparent from recital 7 in the preamble to Regulation 864/2007 that the European Union legislature sought to ensure consistency between Regulation 44/2001, on the one hand, and the substantive scope and the provisions of Regulation 864/2007, on the other, that does not mean, however, that the provisions of Regulation 44/2001 must for that reason be interpreted in the light of the provisions of Regulation 864/2007. The objective of consistency cannot, in any event, lead to the provisions of Regulation $44 / 2001$ being interpreted in a manner which is unconnected to the scheme and objectives pursued by that Regulation. ${ }^{31}$

Also in Lazar v. Allianz SPA, ${ }^{32}$ the central question referred to the CJEU for preliminary ruling by an Italian court was whether Article 4(1) of Rome II had to, in order to determine the law applicable to a non-contractual obligation arising from a road traffic accident, be interpreted as meaning that the damage arising from the death of a person in such an accident, which occurred in the Member State of the court siesed, sustained by close relatives of the deceased who resided in another Member State, had to be regarded as damage or as "indirect consequences" of that accident, within the meaning of

\footnotetext{
${ }^{27}$ See also all cases in $\mathrm{n} 25$.

${ }^{28}$ See also recital 7 to Rome I.

${ }^{29}$ See generally Hillside (n 1); Ertse Group (n 11).

${ }^{30}$ (Case C-45/13) EU:C:2014:7. The CJEU decided, after hearing AG Jääskinen, to proceed to judgment without an opinion.

${ }^{31}$ Ibid at [20].

32 (Case C-350/14) EU:C:2015:802. 
that provision. Suffice it to say that in the Opinion of AG Wahl, ${ }^{33}$ and decision of the CJEU, ${ }^{34}$ they were "indirect consequences" of that accident under Article 4(1) of Rome II.

AG Wahl made explicit reference to recital 7 to Rome II as a legal basis for his opinion. ${ }^{35} \mathrm{He}$ relied on the explanatory report to Rome II, ${ }^{36}$ which made explicit reference to the case law of Article 5(3) of both the Brussels Convention and Brussels I Regulation, to stress the point that both Article 4(1) of Rome II and Article 5(3) of Brussels I make a distinction between direct and indirect damage. ${ }^{37}$ He then justified his reference to the case law ${ }^{38}$ of Article 5(3) of Brussels Convention and Brussels I on the basis of coherence of interpretation. He said:

although the objectives pursued by each of those legal acts are somewhat different, the concepts referred to in the Rome II Regulation must, as far as possible, be understood by reference to the interpretations adopted in connection with the Brussels Convention or the Brussels I Regulation. A degree of parallelism must be established in the interpretation of those notions in so far as the legal instruments all pursue an objective of the foreseeability of the solutions adopted. ${ }^{39}$

Significantly, though the CJEU made explicit reference to recital 7 to Rome II as a legal basis for its decision, it did not explicitly apply the coherence of interpretation nor did it apply its case law under both Article 5(3) of the Brussels Convention and Brussels I (as was done by AG Wahl in his Opinion). The CJEU reached its decision within the confines of Rome II. ${ }^{40}$

In this connection, Professor Dickinson rightly submits that the CJEU “... wished to underplay the links between the two Regulations, and to encourage the future judicial development of the Rome II Regulation principally by reference to its own wording and objectives". ${ }^{41} \mathrm{He}$ also submits that:

Although a weakening of the ties between the two Regulations might, by diluting the significance of comparative case law, prolong the period in which the interpretation of the Rome II Regulation's rules remains unsettled and ferment the risk of inconsistency between national courts, a degree of independent interpretation may be no bad thing in the longer term: the character and objectives of rules of applicable law differ from those of rules of jurisdiction. Recital (7) presents no obstacle to an approach which allows the Rome II Regulation the freedom to develop independently, as consistency does not demand complete fidelity. ${ }^{42}$

\footnotetext{
${ }^{33}$ Opinion of AG Wahl in Case C-350/14, Lazar v. Allianz SPA, EU:C:2015:586 [85].

${ }^{34}$ (n 32) [30].

35 (n 33) [4], [49].

${ }^{36}$ Explanatory memorandum from the Commission, accompanying the Proposal for Rome II, COM(2003) 427final (Explanatory Memorandum) 12.

${ }^{37}$ (n 33) [48]-[49].

${ }^{38}$ Bier (n 25); Dumez France (n 25); Shevill (n 25); Marinari (n 25); Case C-168-02, Kronhofer EU:C:2004:364; ZuidChemie (n 25). These cases were cited in the opinion of AG Wahl in Lazar (n 33) [55]-[65].

${ }^{39}$ Opinion of AG Wahl in Lazar (n 33) [52].

${ }^{40}$ For example the CJEU made explicit reference to Arts 2 and 15 (c) \& (f) of Rome II to justify its decision - an approach which AG Wahl did not take. See Lazar (n 32) [5], [6], [7], [22], [26], [27].

${ }^{41}$ A Dickinson, "Fatal Accidents - the Law Applicable to Claims by Family Members" (2016) Law Quarterly Review 212, 214.

${ }^{42} \mathrm{Ibid}$. 
Whilst there is merit to Professor Dickinson's view that equivalent concepts in Brussels Ia (and its predecessor instruments) should not be blindly applied to Rome II (and vice versa), it would seem odd that a coherence of interpretation between Article 7(2) of Brussels Ia and Article 4(1) of Rome II should not be the norm, when the foundation of direct damage for non-contractual obligations in EU private international law for civil and commercial matters is the jurisprudence of the ECJ interpreting Article 5(3) of the Brussels Convention. ${ }^{43}$

The approach of explicitly utilising the coherence of interpretation in recital 7 to Rome II enriches the jurisprudence of the CJEU by making its judgment more robust, and simplifies the task for national courts. It would also reduce litigation and transaction costs for the parties in the sense that their lawyers will be almost certain that the concept of direct damage would be given an equivalent meaning under Article 7(2) of Brussels Ia and Article 4 of Rome II. The complexity of the work of the lawyer in advising the client is thus reduced. This also leads to sound administration of justice if clients can afford the services of lawyers because the task of the lawyer is simplified and the lawyer can advise the client in a timely manner. Indeed, if Brussels Ia and Rome II have equivalent concepts it is not a bad idea to carefully draw inspiration from previous jurisprudence of the CJEU that have applied those concepts.

Fortunately common law judges have adopted this pragmatic approach in giving the concept of place of direct damage in Article 4(1) of Rome II and Article 7(2) of Brussels Ia an equivalent meaning. Thus, in Allen v. Deputy International Ltd, ${ }^{44}$ Stewart $\mathrm{J}$ in response to the caution expressed by the CJEU in Kainz ${ }^{45}$ correctly held that:

The fact that the Kainz case... determines that the provisions of Regulation 44/2001 must not, for the reason of consistency, be interpreted in the light of Rome II, does not mean that the converse should not apply. There is good reason for recital (7) to Rome II. It refers to consistency in the "substantial scope and provisions" (emphasis added). I accept that Rome II should not be a slave to the objective of consistency and that this objective should not lead to Rome II being interpreted in a manner unconnected to the scheme and objectives which it pursues. However, the court should where possible give effect to recital (7). ${ }^{46}$

In Ertse Group ${ }^{47}$ the English Court of Appeal was concerned with identifying the place of financial damage for the purpose of applying Article 4(1) of Rome II. The gist of the case was that the claimant made a claim for service out of jurisdiction on Russian defendants in respect of a loan agreement and guarantee that was subject to English law and jurisdiction. The claimant alleged that the Russian defendants conspired to put their assets beyond the reach of creditors. The place of payment in respect

\footnotetext{
${ }^{43}$ Explanatory Memorandum (n 36) 11.

${ }^{44}$ [2014] EWHC 753(QB).

${ }^{45}$ Kainz (n 30).

${ }^{46}$ Allen v Deputy International Ltd (n 44) [13] (footnote omitted).

47 (n 11). 
of the loan transaction was in New York. One of the questions before the Court was to determine the place where the financial damage occurred within the meaning of Article 4(1) of Rome II.

Though the Court of Appeal conceded that Article 4 of Rome II and Article 5(3) of Brussels I were different in the sense that the "latter contemplates that a claimant in tort may choose between the courts of the place where the harmful event occurred and the place where the damage was sustained... the purpose of Rome II is to identify a single applicable law rather than a choice", ${ }^{48}$ it held by expressly referring to recital 7 to Rome II that "the Rome II Regulation ought to be interpreted in a manner which is broadly in harmony with the jurisprudence and interpretation of similar provisions in the Judgments Regulation." 49

The Court of Appeal also applied the CJEU jurisprudence in Article 5(3) of Brussels I to the effect that both it and Article 4(1) of Rome II exclude the place where any indirect consequences of the event giving rise to the damage occur. ${ }^{50}$ On this basis, the Court of Appeal held that the loss allegedly suffered within the meaning of Article 4(1) of Rome II was the conspiracy of the Russian defendants to damage the claimant's right to payment under the loan and guarantee agreement. On the contrary, the non-payment of the facility agent to the claimant in London was merely an indirect consequence of the defendant's payment in New York. ${ }^{51}$

In the case of Hillside, ${ }^{52}$ the court was concerned with the interpretation of place of damage under Article 4(1) of Rome II in the context of financial loss arising from gambling. In this case, the Norwegian defendant threatened to sue an English gambling company in Norway for the losses he (the defendant) suffered while gambling on the claimants' website. The claimants (an English gambling company) in response claimed against the Norwegian defendant in the English High Court for a declaration that it was not liable to the defendant in respect of any potential judgment the defendant obtains in Norway. One of the questions the High Court had to determine was whether the place where the damage occurred (under Article 4 of Rome II) in respect of the gambling financial loss suffered by the defendant was in England or Norway. The High Court in essence held that the place where the damage occurred was in England.

In reaching that decision (of the place where the damage occurred), the High Court made express reference to recital 7 to Rome II, and applied the coherence of interpretation, by applying the CJEU jurisprudence under Article 5(3) of the Brussels Convention and Brussels I to the effect that the "place where the damage occurred" under Article 4 of Rome II, was equivalent to the place where

\footnotetext{
${ }^{48}$ Ibid.

${ }^{49} \mathrm{Ibid}$ at [90].

${ }^{50}$ Ibid at [92]

${ }^{51}$ Ibid at [96]. See also Committeri (n 11) [33], [40]-[49]; FM Capital Partners Ltd v Marino [2018] EHWC 1708 (Comm) [490]-[497].

52 (n 1). 
it "directly produced its harmful effects upon the person who is the immediate victim of that event" within the meaning of the CJEU's case law under Article 5(3) of the Brussels Convention and Brussels I. $^{53}$

\section{Place of damage occurs in different countries}

There is the possibility that the direct damage might occur simultaneously in more than one country. In such a case, is a common law court to apply a single law, or different laws depending on the places where the direct damage occurs? In this connection, the Explanatory Memorandum to Rome II provides that: "The rule entails, where damage is sustained in several countries, that the laws of all the countries concerned will have to be applied on a distributive basis, applying what is known as 'Mosaikbetrachtung' in German law." 54

None of the recitals to Rome II explicitly provides a solution to this problem. At best recital 15 to Rome II highlights the issue, but does not provide a solution. It provides that:

The principle of the lex loci delicti commissi is the basic solution for non-contractual obligations in virtually all the Member States, but the practical application of the principle where component factors of the case are spread over several countries varies. This situation engenders uncertainty as to the law applicable.

Some common law judges have regarded this issue as a controversial one, and have expressed tentative views. ${ }^{55}$ In Mxl Limited (a company incorporated in Israel) Ses S.A. (a company incorporated in Luxembourg v Farahzad ( "Farahzad"), ${ }^{56}$ Marcus Smith J in that case held that:

In my judgment, the applicable law is not the place where the damage predominantly occurs. That is not what the Article says. Article 4(1) refers to the "the law of the country in which the damage occurs." The natural meaning is that where damage occurs across several jurisdictions, there will be several applicable laws. ${ }^{57}$

We do not agree with the solution advanced by the Explanatory Memorandum and Marcus Smith J in Farahzad. It is submitted here that the correct and pragmatic approach is that a single law should apply. The better solution in such a case would be to apply the law of the place of principal damage to all the claims arising out of the tort. Where the law of the place of principal damage cannot be identified, the law of the habitual residence of the tortfeasor should apply as a default rule. Applying

\footnotetext{
${ }^{53}$ Ibid at [28].

${ }^{54}$ Explanatory Memorandum (n 36) 11.

${ }^{55}$ Hillside (n 1) [46]; ICDL GCC Foundation (n 12) [9.5]-[9.8]; Innovia Films (n 1) [107]-[111]; Alfa Laval (n 12) 1155 [21]-[24].

56 [2018] EWHC $1041(\mathrm{Ch})$.

${ }^{57}$ Ibid at [44].

10
} 
the habitual residence of the tortfeasor as a default rule to the principal place of damage is justifiable on the basis that it should be regarded as the country of origin from which the direct damage emanates.

This approach of applying a single law would be consistent with recitals 6 and 14 to Rome II that favour the aim of legal certainty and predictability in judicial proceedings. The Explanatory Memorandum and the judgment of Marcus Smith $\mathbf{J}$ in Farahzad must give way to the chief aim of Rome II - legal certainty and predictability.

Second, it is simpler for practitioners and judges to apply a single law to a non-contractual obligation. Applying different laws complicates the exercise, and might lead to delay in judicial proceedings which compromises the sound administration of justice.

Third, commercial necessity requires that a single law should be applied so as to reduce transaction and litigation costs. Pleading and proving a single foreign law is on its own expensive. Why should the parties incur more costs by pleading and proving other foreign laws? Moreover, the sound administration of justice would be compromised where one of the parties cannot fund the case due to lack of resources to plead different laws in a case. Indeed, parties who might expect that a single, less expensive law would resolve their non-contractual obligations would be disappointed to discover that different laws (which are expensive to plead and prove) are to be applied to their dispute.

\section{Article 4(2) of Rome II Regulation}

Article 4(2) of Rome II applies the law of the common habitual residence of the victim and tortfeasor in determining the applicable law. In this connection recital 18 to Rome II provides that:

Article 4(2) should be seen as an exception to this general principle [Article 4(1)], creating a special connection where the parties have their habitual residence in the same country. ${ }^{58}$

In reality, Article 4(2) is an automatic exception to Article 4(1). Once Article 4(2) applies, Article 4(1) is automatically displaced, except where Article 4(1) is manifestly more closely connected to another country.

Article 23 of Rome II provides a definition of habitual residence for parties acting in the course of their business. Article 23(1) defines the habitual residence of companies and other bodies, corporate or unincorporated, to be the place of central administration. However, Article 23(1) provides that:

where the event giving rise to the damage occurs, or the damage arises, in the course of operation of a branch, agency or any other establishment, the place where the branch, agency or any other establishment is located shall be treated as the place of habitual residence.

\footnotetext{
${ }^{58}$ The words in square brackets are added into the quotation. 
Article 23(2) provides that the habitual residence of a natural person acting in the course of his or her business activity shall be his or her principal place of business. Rome II does not provide guidance on the determination of a natural person's (not acting in the course of business) habitual residence.

In common law jurisprudence, there are some points worth noting about Article 4(2). First, Article 4(2) is applied as a fixed connecting factor and not a presumption. ${ }^{59}$ Once Article 4(2) applies, the decision-maker regards Article 4(2) as a rule on its own, and would only disregard or displace Article 4(2) where another country is manifestly more closely connected to the tort.

Second, common law judges have rejected the view that Article 4(2) only applies where a single tortfeasor is sued or involved in the tort. ${ }^{60}$ The rationale for this view is that restricting the application of Article 4(2) to where a single tortfeasor is sued is contrary to the legitimate expectations of the parties, upon which Article 4(2) is founded. ${ }^{61}$ It would also exclude the situation of a number of persons injured in a coach crash, for example. ${ }^{62}$ Thus, the natural wording of Article $4(2)$ is that it is applicable where more than one tortfeasor is sued or involved in the tort. ${ }^{63}$

This approach is correct. Interpreting Article 4(2) as only applicable where a single tortfeasor is involved is a very narrow interpretation. Moreover, the fact that Article 4(2) is a strong exception to Article 4(1) does not mean that Article 4(2) should be unduly circumscribed. Article 4(2) should not be applied mechanically or without thought. It must be given some common sense interpretation that suits the realities of cross-border relations in torts. In effect, the approach of the common law judges in interpreting Article 4(2) is attentive to the realities of cross-border relations in torts.

Third, the time at which both parties (victim and tortfeasor) are habitually resident in a particular country where the damage occurred is key in applying Article 4(2), and the time at which proceedings are instituted is disregarded. ${ }^{64}$ Thus, in a motor accident in Germany involving two British nationals, where both were habitually resident in Germany at the time of the accident, ${ }^{65}$ the fact that the parties were both habitually resident in England at the time the proceedings were instituted was irrelevant to engage the Article 4(2) exception. ${ }^{66}$

This approach is correct. To apply Article 4(2) depending on the movement of the parties, or stage of proceedings would introduce an unacceptable level of uncertainty in applying Rome II, which would be at odds with the Regulation's principal objectives. This is a point that has been stressed by

\footnotetext{
${ }^{59}$ See also Moreno (n 12) [47].

${ }^{60}$ Pickard v Motor Insurers' Bureau [2015] EWHC 3421 [17] (Dingemans J); Pickard v Marshall [2017] EWCA Civ 17

[7] (Cranston J).

${ }^{61} \mathrm{Ibid}$.

${ }^{62}$ Ibid.

${ }^{63}$ Ibid.

${ }^{64}$ Jacobs (n 12); Winrow (n 12) [46].

${ }^{65}$ Winrow (n 12) [51].

${ }^{66}$ Ibid [41]-[43].
} 
some English judges in applying Article 4 of Rome II. ${ }^{67}$ It is also worthy of note that this potential uncertainty would affect more the application of Article 4(2), if it were to be applied depending on the movement of the parties, or stage of proceedings (rather than the time the damage occurs). In the case of Article 4(1), the initial damage is always the time at which the damage is sustained - any further damage in another country would be an indirect consequence of the tort. However, in Article 4(2), the parties may both be habitually resident in country A at the time of the damage, but habitually resident in country $\mathrm{B}$, at the time of instituting proceedings.

Fourth, the habitual residence of the person claimed to be liable must be the habitual residence of the tortfeasor; it cannot be the habitual residence of the tortfeasor's insurer. ${ }^{68}$ Thus, for example if $\mathrm{C}$ is the insurer of the tortfeasor, the habitual residence of $\mathrm{C}$ is irrelevant for the purpose of determining Article 4(2). This interpretation of Article 4(2) can only be correct. The tortfeasor is primarily liable to the victim of the tort and in reality the tortfeasor's insurer has no relationship with the victim of the tort. The tortfeasor's insurer only comes into the picture when the tortfeasor causes damage to the victim. To hold that the habitual residence of the person claimed to be liable includes the habitual residence of the insurer of the tortfeasor would lack common sense and lead to uncertainty.

Fifth, Article 23 does not provide a definition of habitual residence for natural persons not acting in the course of business. In this connection, common law judges have filled the gap. It has been held that habitual residence is an autonomous concept. ${ }^{69}$ In effect, habitual residence is predominantly a question of fact rather than intention. ${ }^{70}$ In abstract terms, habitual residence of a natural person, not acting in the course of business, is defined as residence having a certain degree of permanence (stability) in a particular State or country. In Winrow the claimant's habitual residence was analysed as follows:

The claimant had been living and working in Germany for eight and a half years by the time of the accident. She was living there with her husband and three of their children were at school in Germany. The family remained living in Germany for a further 18 months after the accident. There was no evidence that during that time the family had a house in England. The residence of the claimant in Germany was established for a considerable period of time. The fact that the claimant and her family were living in Germany because the army had posted her husband there and that it was not his first choice did not render her presence there involuntary. He and his family were living in Germany because of his job. The situation of the claimant in Germany was similar to that of the spouses of other workers posted abroad. This is not an unusual situation. Having regard to the length of stay in the country, its purpose and the establishing of a life there - three

\footnotetext{
${ }^{67}$ Ibid at [52].

${ }^{68}$ Jacobs (n 12) [39]; Winrow (n 12) [39].

${ }^{69}$ Winrow (n 12) [40] - reliance placed on In Re LC (Children) [2014] 2 WLR; $A v A$ (Children: Habitual Residence) [2014] AC 1; Mercredi v Chaffe (Case C-497/10 PPU) [2012] Fam 22 [47].

${ }^{70}$ Winrow (n 12) [40]. 
children were in an army run school in Germany and the claimant worked at an army base school - in my judgment the habitual residence of the claimant at the time of her accident was Germany. ${ }^{71}$

This approach is correct. It may have been tempting for a common law judge to confuse domicile with habitual residence. If the concept of domicile had applied in the above case, English law would have applied on the basis that the claimant did not intend to make Germany her permanent abode.

\section{E. Article 4(3) of Rome II Regulation}

Article 4(3) displaces Article 4(1) and (2) where there is a manifestly closer connection with another country. In this connection recital 18 to Rome II provides that:

Article 4(3) should be understood as an 'escape clause' from Article 4(1) and (2), where it is clear from all the circumstances of the case that the tort/delict is manifestly more closely connected with another country.

In addition, recital 14 to Rome II provides that:

The requirement of legal certainty and the need to do justice in individual cases are essential elements of an area of justice. This Regulation provides for the connecting factors which are the most appropriate to achieve these objectives. Therefore, this Regulation provides for a general rule but also for...an 'escape clause' which allows a departure from these rules where it is clear from all the circumstance of the case that the tort/delict is manifestly more closely connected with another country. This set of rules thus creates a flexible framework of conflict-of-law rules. Equally, it enables the court siesed to treat individual cases in an appropriate manner.

In this connection, some common law judges have observed that "escape clause" and "flexible framework" are not defined in the recitals. ${ }^{72}$ However, one of the authors of this article has provided the following definition:

An escape clause is a provision inserted in a legal instrument to supplement or cure the defect in the principal connecting factor, where the law designated by the principal connecting factor has little or no connection with the dispute to be resolved before the court. Escape clauses honour the claim that no legal instrument is perfect and strive to improve the instrument by giving the court the discretion to locate the law of a country that is more or most closely connected with the subject-matter. In effect, escape clauses exist in choice of law because there is no connecting factor that is a perfect answer to the determination of the applicable law in the absence of choice.

The escape clause honours the claim that rigid choice of law rules would not always satisfy the requirement of proximity. In effect, the role of the escape clause is to introduce flexibility in the

\footnotetext{
${ }^{71}$ Ibid $[41]$.

${ }^{72}$ OPO (n 17) [98]. See also M Pauknerová, "Escape Clauses and Legal Certainty in Private International Law" (2016/2017) XVIII Yearbook of Private International Law 61. 
settlement of the conflict of laws and to best designate the country or legal system with the closest connection to the dispute. ${ }^{73}$

The following points are worth noting on how the escape clause operates in English and Irish courts. First, the parties can explicitly or implicitly agree to exclude the operation of Article 4(3), and restrict their argument to Article 4(1) and Article 4(2). ${ }^{74}$ This approach saves time for both the parties and the court and also reduces litigation and transaction costs.

Second, the burden of proof is on the party who wishes to displace Article 4(1) or Article 4(2), in order to apply Article 4(3). ${ }^{75}$ If for example party A argues that Article 4(3) is applicable to his case in order to displace Article 4(1) or Article 4(2), the burden of proof rests on party A to demonstrate why Article 4(3) should apply. In addition, if party A seeks to rely on Article 4(3) in order to displace Article 4(1) or Article 4(2) but does not rely on it before the court the judge is not obliged to consider the application of Article 4(3).

In this connection, common law judges regard the standard of proof as high. ${ }^{76}$ In effect, they have described the criteria for applying Article 4(3) as "exceptional" 77 and that the main rule should not "generally be disapplied", ${ }^{78}$ because there is a "high standard"79 or "high threshold", ${ }^{80}$ or "high hurdle" to invoke the escape clause. ${ }^{81}$

By way of analogy, common law judges have held that the use of the phrases "clear from all the circumstances of the case" and "manifestly more closely connected" in Article 4(3) of Rome I indicate that the escape clause is an exceptional remedy that is to be rarely utilised in determining the law of a country that applies to a contract between the parties in the absence of choice. ${ }^{82}$ In effect, the CJEU jurisprudence interpreting the escape clause under the Rome Convention has to be followed with caution. ${ }^{83}$ As Popplewell J rightly holds:

The text and architecture of Article 4 of the Rome I Regulation is very different from that of the Rome Convention. In particular, the test is no longer expressed as one of closest connection; the test is that contained in the rules set out in Article 4.1 and 4.2, which are no longer expressed as presumptions or as being subject to the closest connection test; and the closest connection test has become an "escape clause" to be applied only where it is clear that the connection is manifestly closer to a country other

\footnotetext{
${ }^{73}$ CSA Okoli, Place of Performance: A Comparative Analysis (Hart, 2020) - forthcoming.

${ }^{74}$ Farahzad (n 56) [32].

${ }^{75}$ Stylianou (n 12) [57]; Winrow (n 12) [42].

${ }^{76}$ Winrow ibid.

${ }^{77}$ Fortress Value (n 12) [47]; Stylianou (n 12) [61], [64]; Moreno (n 12) [47].

${ }^{78} \mathrm{OPO}$ (n 17) [112].

${ }^{79}$ Winrow (n 12) [42].

${ }^{80}$ Pan Oceanic Chatering Inc v UNIPEC UK Co Ltd [2016] EWHC 2774 (Comm) [209] (Carr J).

${ }^{81}$ Winrow (n 12) [63]; Pickard v Motor Insurers' Bureau (n 60) [20]; Pickard v Marshall (n 60) [8]; Rai v The Ministry of Defence [2016] 5WLUK 135 [117] (Mark Gargan J); Committeri (n 11) [57].

${ }^{82}$ See the Explanatory Memorandum (n 36) 12.

${ }^{83}$ See generally Case C-133/08, Intercontainer (n 12); Case C-64/12 Schlecker (t/a Firma Anton Schlecker) v. Boedeker, EU:C:2013:551; Case C-305/13, Haeger \& Schmidt GmbH v Mutuelles du Mans assurances IARD (MMA IARD) and others EU:C:2014:2320.
} 
than that dictated by the tests in Article 4.1 and 4.2, so that they are to be disregarded. The word "clear" reflects what the ECJ had already said was the effect of Article 4.5 of the Rome Convention in the Interfrigo case, but the word "manifestly" suggests a more stringent standard than before, as does the elevation of the criteria in Article 4.1 and 4.2 to tests from mere presumptions of closest connection. The new language and structure suggests a higher threshold, which requires that the cumulative weight of the factors connecting the contract to another country must clearly and decisively outweigh the desideratum of certainty in applying the relevant test in Article 4.1 and 4.2. ${ }^{84}$

Third, common law judges rightly hold that all the circumstances of the case must be considered in interpreting Article 4(3), and reject a narrow approach in applying the escape clause. ${ }^{85}$ Thus, in one decided case Mark Gargan J rightly rejected the argument of counsel for one of the parties that a judge has to be $80 \%$ sure before he can effectively deploy Article $4(3) .{ }^{86} \mathrm{He}$ also rightly rejected the argument of counsel that the test of proof beyond reasonable doubt, which is the standard of proof for criminal proceedings applied to Article 4(3). ${ }^{87}$ In effect, common law judges do not unduly circumscribe the operation of Article 4(3).

Fourth, Article 4(3) is very fact dependent. In other words, Article 4(3) operates based on the circumstances of the case. It is impossible to provide a precise criteria on how Article 4(3) works based on common law jurisprudence and practice.

Fifth, Article 4(3) is not only used to displace Article 4(1) and Article 4(2). In common law practice, it can be used to confirm the application of Article 4(1) or (2). ${ }^{88}$ For example, if on the facts of a case Article 4(1) or (2) is the country of closest connection, the application of Article 4(3) can be used to confirm the correctness of applying Article 4(1) or Article 4(2).

In practice, it can also be used to mediate between Article 4(1) and Article 4(2), so that although on the facts of a case Article 4(2) displaces Article 4(1), Article 4(3) can be used to restore the application of Article 4(1) based on a manifestly closer connection the tort has with the place of direct damage. ${ }^{89}$ For example, party A injures party B in a car accident in the Netherlands. Party A and $\mathrm{B}$ are both nationals of The Netherlands. The car involved in the accident was bought in The Netherlands, and is insured by a Dutch company. Party A and B both work for a subsidiary company (in Nigeria) of a Dutch parent company, and their employment relationship is governed by Dutch law. However, Party A and B have their common habitual residence in Nigeria. In this scenario, though on the facts of the case Article 4(2) automatically displaces Article 4(1) for Nigerian law to apply, Dutch

\footnotetext{
${ }^{84}$ Molton Street Capital LLP v Shooters Hill Capital Partners LLP, Odeon Capital Group LLC [2015] EWHC 3419 [94].

${ }^{85}$ Stylianou (n 12) [62]; Winrow (n 12) [43]; OPO (n 17) [112] (Arden LJ); Pickard v Motor Insurers' Bureau (n 60) [21]; Pickard v Marshall (n 60) [13]-[20]. See also Pan Oceanic Chartering (n 81) (Carr J).

${ }^{86}$ Rai $v$ The Ministry of Defence (n 82) [113].

${ }^{87}$ Ibid.

${ }^{88}$ Hillside (n 1) [46].

${ }^{89}$ See generally Pickard v Motor Insurers' Bureau (n 60) [17]; Pickard v Marshall (n 60). 
law is applicable under Article 4(3) because The Netherlands is manifestly more closely connected with the tort than Nigeria.

Sixth, in interpreting Article 4(3) of Rome II, though all the circumstances of the case are to be considered, in common law practice some factors are more important than others. For example Article 4(1) and Article 4(2) are very relevant in interpreting Article 4(3), so that if Article 4(1) and (2) point to the same country, that is a very strong indicator (if not decisive) under Article 4(3) that the country in question is the applicable law. ${ }^{90}$ In reality, this is another way of saying that where Article 4(1) and Article 4(2) point to the same country, it is almost impossible to use Article 4(3) to displace Article 4(1) and Article 4(2).

A pre-existing contractual relationship between the parties is a very significant (though not decisive) connecting factor that can trigger the application of Article 4(3) in displacing Article 4(1) or (2). ${ }^{91}$ Thus, in the Irish case of Allied Irish Bank Plc and others v Diamond and Others ${ }^{92}$ there were different contractual and non-contractual relationships and causes of action (involving multiple parties) before the court. In a bid to consolidate proceedings, the court utilised Irish law under Article $4(3)$ because it governed all the employment relationships between the parties in the case. ${ }^{93}$

It is controversial among common law judges whether pursuit of proceedings in a particular country is a very relevant connecting factor that can trigger the application of Article 4(3). Sir Robert Nelson $J$ held that the pursuit of proceedings in a particular forum is an important factor in interpreting Article 4(3), ${ }^{94}$ while Slade J held that pursuit of proceedings in a particular forum is "not a strong connecting factor" in interpreting Article 4(3). ${ }^{95}$ In this connection, it is submitted that it is Slade J who holds the correct view. To regard the pursuit of proceedings in a particular forum as an important factor in interpreting Article 4(3) is misconceived because it conflates choice of law with jurisdiction, as if they were the same. Moreover, such an interpretation encourages forum shopping. A party would simply invoke a particular forum just to gain the advantage of applying the law of the forum. This is not to say applying the law of the forum is a bad thing; it is actually a good thing if done legitimately within the confines of Rome II. In effect, the applicable law cannot be determined based on what court assumes jurisdiction in the EU. Indeed, recital 6 to Rome II provides that:

The proper functioning of the internal market creates a need, in order to improve the predictability of the outcome of litigation, certainty as to the law applicable and the free movement of judgments, for the

\footnotetext{
${ }^{90}$ Winrow (n 12) [43], [62].

${ }^{91}$ Allied Irish Bank (n 16) [4.19]-[4.20]. See also Hillside (n 1) [46]. Cf. Alfa Laval (n 12) [21]-[24]; Erste Group (n 11) [97].

92 (n 12).

${ }^{93}$ In Hillside (n 1) [46] English law which was held to be the applicable law of the contract between the claimant and defendant, was utilised as one of the significant connecting factors to govern their non-contractual obligation under Art 4(3) of Rome II. Though in this case, Art 4(3) was used to confirm the application of Art 4(1) rather than to disapply it. ${ }^{94}$ Stylianou (n 12) [79]-[82].

${ }^{95}$ Winrow (n 12) [61]. 
conflict-of-law rules in the Member States to designate the same national law irrespective of the country of the court in which an action is brought.

Sir Robert Nelson J's interpretation breaches the provisions of Recital 6 to Rome II and should be regarded as decided in error.

In common law practice, other less relevant factors in interpreting Article 4(3) of Rome II are the place of indirect damage or consequential loss, factors relating to the parties, habitual residence of the parties at the time of judicial proceedings (if different from the time the damage occurred), common nationality, habitual residence of the tortfeasor's insurer which is joined as a party, and the place where the motor vehicle was insured and registered in the case of a traffic accident. ${ }^{96}$

Seventh, some common law judges have held that there is a strong relationship between the common law concept of forum non conveniens and Article 4(3), though they are not to be confused as one and the same. ${ }^{97}$ As Lord Sumption rightly holds:

It is undoubtedly convenient for the country of the forum to correspond with that of the proper law. It is also true that both jurisdiction and choice of law can broadly be said to depend on how closely the dispute is connected with a particular country. ${ }^{98}$

Thus, if the tort is manifestly more closely connected with a particular country under Article 4(3), that country would qualify as the natural forum under the concept of forum non conveniens. In effect, a useful comparison and analogy can be made between the concept of closest connection and forum non conveniens. This is a very interesting point that requires further academic study. ${ }^{99}$

In the final analysis, it is suggested that one must be careful not to use the concept of stare decisis to slavishly interpret Article 4(3) of Rome II. A connecting factor which is less significant or irrelevant in one case, might turn out to be a strong connecting factor in interpreting Article 4(3) of Rome II in another case. In effect, care must be taken to ensure that one is unfettered by precedent in interpreting Article 4(3) of Rome II. The facts of the instant case must be carefully evaluated before deciding whether the application of Article 4(3) has been triggered. Of course, these common law decisions will continue to serve as guides particularly for practitioners, but they should not be applied unthinkingly in interpreting Article 4(3).

\section{F. Conclusion}

\footnotetext{
${ }^{96}$ Winrow (n 12) [39], [48]- [60]; Stylianou (n 12) [50]; Alliance Bank (n 1). On the concept of forum non conveniens see generally Spiliada Maritime Corporation v. Cansulex Ltd. [1987] AC 460.

${ }^{97}$ Stylianou (n 12) [63]-[64], [83].

${ }^{98}$ Brownlie (n 17) [77].

${ }^{99}$ The first author is interested in doing some empirical study on the concept of forum non conveniens. 18
} 
Rome II has been in operation for over ten years. No legislator or scholar could have exhaustively envisaged how Article 4 of Rome II would work in practice. It is the judge's role to interpret the law and this requires that the judge clarifies ambiguities and, on occasion, fill gaps that might arise from the application of legislative provisions in cross-border litigation. If one were to ask: how do we rate the judgments of English and Irish courts on Article 4 of Rome II? Our general response would be "excellent". The decisions of English and Irish courts on Article 4 of Rome II have generally been consistent, harmonious, insightful, and impressive. This is not to say they have been perfect in interpreting Article 4 of Rome II. Perfection is a utopia.

Section C dealt with the operation of Article 4(1) of Rome II. First, a coherence of interpretation is desirable between Article 4(1) of Rome II and Article 7(2) of Brussels Ia in interpreting the concept of direct damage. Second, where the place of damage occurs in different countries, a single law should be identified to govern the entire tortious claim.

Section D dealt with the operation of Article 4(2) of Rome II. Article 4(2) operates as an automatic exception to Article 4(1). First, the concept of a non-business natural person's common habitual residence is not defined within the measure but it is to be viewed as distinct from the concepts of common domicile, common nationality and common ordinary residence. Second, the time at which the damage occurs, and not the time proceedings are instituted, is used in applying Article 4(2).

Section E dealt with the operation of Article 4(3) of Rome II. Article 4(3) operates as an escape clause to Article 4(1) and Article 4(2). It is to be applied exceptionally, though its operation is not to be unduly circumscribed. All the circumstances of the instant case must be taken into account in interpreting Article 4(3) and determining what weight is to be given to the connecting factors in issue.

The decisions observed within this article demonstrate that English and Irish judges have remained true to the spirit of the measure of their interpretation and application of Rome II, despite the fact that its present rules present a regime so distinct from that which was previously in place in England and Ireland. In this regard, they have approached the measure with caution so as not to exercise their usual degree of judicial discretion. Such an approach would be at odds with the Regulation's chief objective of attaining legal certainty and consistency of outcome. In their approach, English and Irish judges have averted the propensity to apply the law of the forum, known as the 'homing instinct' and correctly interpreted the legislative intention that lies behind Article 4 - long may it continue. 